\title{
Relationship between Anti-CCP Antibodies and Oxidant and Anti-0xidant Activity in Patients with Rheumatoid Arthritis
}

\author{
Levent Ediz ${ }^{1 凶}$, Ozcan Hiz¹, Halil Ozkol², Elif Gulcu¹, Murat Toprak¹, Mehmet Fethi Ceylan³ \\ 1. Yuzuncu Yil University, Medical Faculty, Department of Physical Medicine Rehabilitation and Rheumatology, Van, \\ Turkey; \\ 2. Yuzuncu Yil University, Medical Faculty, Department of Medical Biology, Van, Turkey; \\ 3. Yuzuncu Yil University, Medical Faculty, Department of Orthopaedics, Van, Turkey
}

$\triangle$ Corresponding author: Associate Professor Levent Ediz, MD, PhD. Yuzuncu Yil University, Medical Faculty, Department of Physical Medicine and Rehabilitation, 65100 Van, Turkey. Tel.:+90 432 2150182; fax:+90 432 2168352. E-mail address: leventediz@gmail.com

Received: 2010.12.09; Accepted: 2011.02.01; Published: 2011.02.09

\begin{abstract}
Objective/Aim: A new group of autoantibodies in Rheumatoid Arthritis (RA), the anti-cyclic citrullinated peptide (anti-CCP) antibodies directed to citrulline-containing proteins, which are of value for the severity of RA. Up to date, the relationship between anti-CCP antibodies and oxidant, anti-oxidant activity in patients with RA has not been elucidated in the previous studies. In this study we aimed to investigate the effect of anti-CCP antibodies in the circulation on whole blood, serum and synovial fluid oxidant and anti-oxidant activity in patients with RA. Materials and Methods: RA patients with anti-CCP $(+)(n=25)$ and anti-CCP (-) $(n=24)$ were recruited into the study. All patients had a positive rheumatoid factor (RF). The patients who were under treatment with only non-steroidal antiinflammatory drugs (NSAID) at the study time included in the study. Catalase (CAT), Glutathione peroxidase (GSHPx), Myeloperoxidase (MPO) activities and the levels of Malondialdehyde (MDA) were measured in whole blood, serum and synovial fluid in both groups. Results: There were no significant differences in terms of the mean whole blood and serum antioxidative activity (CAT, GSHpx) and the mean blood and serum MDA and MPO values (oxidative activity), between the patients with anti-CCP(+) and those with anti-CCP(-). There was increased synovial oxidant activity (MDA and MPO levels) $(P<0.05)$ in anti-CCP $(+)$ RA patients with or without ESR negativity when compared with anti-CCP(-) RA patients. There was positive correlation between anti-CCP antibody levels and synovial MDA and MPO levels $(r=0.435, p<0.05$, $r=0.563, p<0.05$ respectively) in anti-CCP $(+)$ group. Conclusions: In conclusion, anti-CCP antibody positivity seems to be associated with increased synovial fluid oxidant activity (increased MDA and MPO levels) in patients with RA. These conclusions need to be validated in a larger controlled study population.
\end{abstract}

Key words: Oxidative stress; Rheumatoid arthritis; Anti-CCP antibody; Malondialdehyde; Myeloperoxidase; Synovial fluid

\section{Introduction}

Rheumatoid Arthritis (RA) is a chronic, inflammatory, autoimmune, systemic disease, in which various joints in the body are inflamed, leading to swelling, pain, stiffness, and the possible loss of func- tion. Pathologically, synovial proliferation and destruction of the articular cartilage and bone occur in the disease course [1]. Free radical/reactive oxygen species (ROS) can be defined as a chemical species, an 
atom or a molecule that has one or more unpaired electrons in its valance shell which makes it unstable, short lived and highly reactive, therefore, for gaining stability, it attacks the nearest stable molecule "stealing" its electron. When the attacked molecule looses its electron, it becomes a free radical itself, beginning a chain reaction cascade resulting in disruption of a living cell [2]. It is well established now that free radicals/ROS play an important role in chronic inflammation [2]. Oxygen metabolism has an important role in the pathogenesis of RA. Free radicals/ROS produced in the course of cellular oxidative phosphorylation and repetitive cycles of hypoxia and reoxygenation, along with oxidants produced by phagocytic cells such as macrophages and neutrophils, lead to chronic oxidative stress in the RA synovial microenvironment and the other tissues [3].

Increased oxidative stress in synovial tissue and synovial fluid may be associated with increased disease activity, tissue demage and bone erosions in RA. It has been shown that, especially in RA, monocytes produce 2.7 times more oxygen radicals than controls [4]. Clinical evidence has also suggested oxidative stress is elevated in RA patients. Plasma malondialdehyde (MDA), a degradation product of lipid peroxidation, level was significantly higher in the synovial fluid and serum of RA patients than that of control subjects [5,6]. Epidemiologic studies have also shown an inverse association between dietary intake of antioxidants and RA incidence [7], and inverse associations between antioxidant levels and inflammation have been found $[8,9]$.

A new group of autoantibodies that have generated particular interest are the anti-cyclic citrullinated peptide (anti-CCP) antibodies directed to citrulline-containing proteins, which appear to be of value for the diagnosis and especially severity of RA [10], and also closely correlated to inflammatory disease activity (Disease Activity Score-DAS28) scores and the presence, development, and extent of joint erosions [1]. Anti-CCP antibodies are actively produced or enriched at the site of inflammation (joints and synovial tissue) and may play an active role in the pathogenesis of Anti-CCP positive RA by enhancing oxidative stress in rheumatoid joint [11]. Indeed, high titers of anti-CCP antibodies have been associated with an erosive disease course and outcome in RA $[1,10,12]$. Anti-CCP antibodies can also induce or enhance arthritis and tisuue demage in the mouse [13].

The effects of anti-CCP antibodies on whole blood, serum and synovial fluid oxidant and anti-oxidant activity in patients with RA has not been elucidated in the previous studies. In this study we aimed to investigate the effect of anti-CCP antibodies in the circulation on whole blood, serum and synovial fluid oxidant and anti-oxidant capacity in patients with RA.

\section{Methods}

RA patients with anti-CCP $(+)(n=25)$ and anti-CCP (-) $(n=24)$ were recruited into the study. All patients fulfilled the revised American College of Rheumatology (ACR) criteria for RA [14]. All patients had a positive rheumatoid factor (RF). RF negative patients were excluded from the study. Consent for all procedures was obtained from each individual and from the university research ethics committee. Blood and synovial fluid samples were taken from the patients. The patients were chosen for the study after having a preliminary evaluation consisting of a brief medical history, smoking and alcohol habits and physical examinations. Inflammatory disease activity was defined as a Disease Activity Score (DAS 28). All patients evaluated in terms of RF, CRP, ESR, and anti-CCP2 status. DAS 28 scores, tender joint count, duration of morning stiffness. Patients with any history of chronic diseases such as liver diseases, diabetes mellitus, respiratory disorders, cardiovascular diseases and alchohol usage and smoking were not included in the study. The patients who were under treatment with only NSAID at the study time included in the study. Those who had been receiving corticosteroid agents and under treatment with disease modifying anti-rheumatic drugs and anti-TNF or other biological agents for at least 3 months before the study date were excluded from this study.

\section{Determination of anti-CCP2 antibody}

Anti-CCP2 antibody was determined by ELISA (Immunoscan RA Mark 2; Euro-Diagnostica, Arnhem, The Netherlands) which was performed according to the manufacturer's instructions (sensitivity 74\%, specificity $97-99 \%$ ).

\section{Determination of oxidant and antioxidant activi- ties in whole blood, serum and synovial fluid}

Totally $5 \mathrm{ml}$ sample of venous blood and $3 \mathrm{ml}$ sample of synovial fluid from knee was taken from each individual in the morning, before breakfast. $2 \mathrm{ml}$ of them was taken in tube with EDTA, and the rest in biochemical tube. Samples were kept in a cool box at $+4{ }^{\circ} \mathrm{C}$ until they were transferred immediately to the laboratory, where they were immediately centrifuged. Serum was stored at $-20^{\circ} \mathrm{C}$ until analysis. The serum samples were obtained by centrifuging blood samples at $3000 \mathrm{rpm}$ for $15 \mathrm{~min}$ at $+4{ }^{\circ} \mathrm{C}$. Whole blood samples and synovial fluid were hemolyzed with distillated water then they were centrifuged at $4000 \mathrm{rpm}$ for 10 
min at $+4{ }^{\circ} \mathrm{C}$. The clear upper supernatant fluid was taken. Catalase (CAT), Glutathione peroxidase (GSHPx), Myeloperoxidase (MPO) activities and the levels of Malondialdehyde (MDA) were measured in whole blood, serum and synovial fluid.

\section{Malondialdehyde (MDA) analysis}

Lipid peroxidation (MDA) levels of whole blood, serum and synovial fluid were measured with the thiobarbituric acid reaction by the method of Placer et al. [15]. The quantification of thiobarbituric acid reactive substances was determined by comparing the absorption to the standard curve of MDA equivalents generated by acid catalyzed hydrolysis of 1,1,3,3 tetramethoxypropane. The optical density was measured at $532 \mathrm{~nm}$ for samples MDA level (Shimadzu UV-VIS Spectrophotometer UV1201). The level of MDA was expressed as $\mathrm{nmol} / \mathrm{ml}$ sample.

\section{Catalase (CAT) analysis}

CAT (EC 1.11.1.6) activity was determined by the method of Aebi [16]. The principle of the assay is based on the determination of the rate constant $\left(\mathrm{s}^{-1}, k\right)$ of the $\mathrm{H}_{2} \mathrm{O}_{2}$ decomposition rate at $240 \mathrm{~nm}$. Activities were expressed as $k \mathrm{ml}^{-1}$ sample.

\section{Glutathione peroxidase (GSH-Px) analysis}

GSH-Px activity of the whole blood, serum and synovial fluid samples was measured spectrophotometrically (Shimadzu 2R/UV-Vis) at 378C and 412 $\mathrm{nm}$ according to Matkovics et al [17]. GSH-Px activity in samples was expressed as units $(\mathrm{U} / \mathrm{ml})$ of GSH-Px activity.

\section{Myeloperoxidase (MPO) analysis}

MPO activity was measured according to the modified method of Bradley et al [18]. MPO activity in the supernatant was determined by adding $100 \mu \mathrm{l}$ of the supernatant to $1.9 \mathrm{ml}$ of $10 \mathrm{mmol} / 1$ phosphate buffer ( $\mathrm{pH}$ 6.0) and $1 \mathrm{ml}$ of $1.5 \mathrm{mmol} / \mathrm{l}$ o-dianisidine hydrochloride containing $0.0005 \%(\mathrm{w} / \mathrm{v})$ hydrogen peroxide. The changes in absorbance at $450 \mathrm{~nm}$ of each sample were recorded on a UV-Vis spectrophotometer. MPO activity in samples was expressed as units $(\mathrm{U} / \mathrm{ml})$ of MPO activity.

\section{Statistical analysis}

Results were expressed as mean and standard deviation (SD). Statistical analysis was carried out using the SPSS program (version 13.0 software, SPSS Inc. Chicago, Illinois, USA). For the comparison of groups, independent student $t$ test and Mann-Whitney U test were used. P values of less than 0.05 were regarded as significant. Spearman rank correlation analysis was applied to assess correlation.

\section{Results}

The RA subjects with anti-CCP $(+)$ were 25 individuals (18 females, 7 males), aged 39 to 63 years (mean age $54.4 \pm 9.6$ ). The mean anti-CCP antibody levels was $96.72 \pm 61.07 \mathrm{U} / \mathrm{ml}($ mean $\pm S D)$ in anti-CCP $(+)$ group. The RA patients without anti-CCP consisted of 24 individuals (19 females, 5 males), aged 42 to 62 years (mean age $56.2 \pm 11.2$ ). As shown in Table 1, RA patients with anti-CCP(+) had significantly higher DAS 28 scores, tender joint count and morning stiffness time $(p<0.01)$ than that of those with anti-CCP(-). Other demographic, clinical and laboratory characteristics did not show statistically significant differences between groups.

There were no significant differences in terms of the mean whole blood and serum antioxidative activity (CAT, GSHpx) and the mean blood and serum MDA and MPO values (oxidative activity), between the patients with anti-CCP(+) and those with anti-CCP(-) (Table 2).

In the synovial fluid, there was increased synovial oxidant activity (MPO and MDA levels) $(p<0.05)$ in anti-CCP(+) patients with RA when compared with anti-CCP(-) RA patients (Table 3). There were no significant differences in terms of the mean synovial antioxidative activity (CAT, GSHpx) values between the patients with anti-CCP(+) and those with anti-CCP(-).

Spearman's correlation showed positive correlations between serum anti-CCP antibody levels and synovial MDA and MPO levels $(r=0.435, \mathrm{p}<0.05$, $\mathrm{r}=0.563, \mathrm{p}<0.05$ respectively) in anti-CCP $(+)$ group (Figure 1). But there were no significant correlations between anti-CCP antibody levels and whole blood and serum MPO, MDA, GSHpx and CAT levels as well as synovial GSHpx and CAT levels in anti-CCP $(+)$ group.

Because of oxygen metabolism (Free radi$\mathrm{cal} /$ reactive oxygen species) is related with inflammation, to reveal the relationship between anti-CCP and synovial fluid oxygen metabolism we examined oxidative status in ESR negative patients. Although, there is no clear rational cut off for activity (or for normality) of ESR in RA, the usual clinical trial activity cutpoints for ESR are $28-30 \mathrm{~mm} / \mathrm{h}$ [19]. For that reason, a cut off value for ESR negativity was assessed as $28 \mathrm{~mm} / \mathrm{h}$. Ten patients in anti-CCP $(+)$ group and 12 patients in anti-CCP(-) group were ESR negative. While only ESR negative patients compared between the groups, there were no significant differences in terms of serum oxidant levels and antioxidant activity $(p>0.05)$. On the other hand, there were still significant differences between the groups in terms of syn- 
ovial oxidant levels (MDA and MPO levels) $(\mathrm{p}<0.05)$ (Table 4). Moreover, there was still a significant positive correlation between serum anti-CCP and synovial fluid MPO levels [r=0.693, $\mathrm{p}<0.05$ - but not synovial fluid MDA levels $(\mathrm{r}=0.480, \mathrm{p}>0.05)]$ in ESR negative patients of anti $\mathrm{CCP}(+)$ group (Figure 2 ).

Table I Demographic and some clinical and laboratory characteristics of RA patients with anti-CCP $(+)$ and anti-CCP (-).

\begin{tabular}{|c|c|c|c|}
\hline Feature & $\begin{array}{l}\text { Anti-CCP(+) }(n=25) \\
(\text { mean } \pm \text { SD) }\end{array}$ & $\begin{array}{l}\text { Anti-CCP(-) }(n=24) \\
(\text { mean } \pm \text { SD) }\end{array}$ & P value \\
\hline Age (years) & $54.4 \pm 9.6$ & $56.2 \pm 11.2$ & NS \\
\hline Gender female/male & $18 / 7$ & $19 / 5$ & NS \\
\hline Body mass index (BMI) kg $/ \mathrm{m}^{2}$ & $24.5 \pm 1.4$ & $25.3 \pm 1.9$ & NS \\
\hline Duration of disease (years) & $9.6 \pm 6.3$ & $8.1 \pm 7.5$ & NS \\
\hline Morning stiffness (minutes) & $34.7 \pm 33.6$ & $17.8 \pm 23.5$ & $0.004^{*}$ \\
\hline Tender joint count & $5.7 \pm 5.2$ & $2.8 \pm 3.3$ & $0.007^{*}$ \\
\hline DAS 28 scores & $4.1 \pm 1.8$ & $3.4 \pm 1.3$ & $0.006^{*}$ \\
\hline ESR mm/hr & $37.9 \pm 26.8$ & $33.6 \pm 21.3$ & NS \\
\hline CRP mg/L & $34.3 \pm 23.8$ & $31.4 \pm 29.8$ & NS \\
\hline
\end{tabular}

${ }^{*} \mathrm{p}<0.01$, NS: Nonsignificant

Table 2 Serum and whole blood oxidant activity; MDA and MPO levels, and antioxidant activity; CAT and GSH-Px levels in anti-CCP(+) and anti-CCP(-) patients with RA.

\begin{tabular}{|c|c|c|c|c|c|}
\hline \multirow{3}{*}{ Serum GSHpx (U/ml) } & Anti-CCP & $\mathbf{N}$ & Mean & Std. Deviation & p value \\
\hline & negative & 24 & 0.47 & 0.25 & 0.622 \\
\hline & positive & 25 & 0.48 & 0.19 & \\
\hline \multirow[t]{2}{*}{ Whole Blood GSHpx (U/ml) } & negative & 24 & 14.10 & 6.67 & 0.614 \\
\hline & positive & 25 & 15.63 & 4.39 & \\
\hline \multirow{2}{*}{$\begin{array}{l}\text { Serum CAT } \\
\left(k \mathrm{ml}^{-1}\right)\end{array}$} & negative & 24 & 0.11 & 0.03 & 0.267 \\
\hline & positive & 25 & 0.13 & 0.01 & \\
\hline \multirow[t]{2}{*}{ Whole Blood CAT $\left(k \mathrm{ml}^{-1}\right)$} & negative & 24 & 114.23 & 21.15 & 0.322 \\
\hline & positive & 25 & 112.21 & 20.66 & \\
\hline \multirow[t]{2}{*}{ Serum MDA (nmol/ml) } & negative & 24 & 3.34 & 0.15 & 0.141 \\
\hline & positive & 25 & 3.52 & 0.32 & \\
\hline \multirow[t]{2}{*}{ Whole Blood MDA (nmol/ml) } & negative & 24 & 50.39 & 7.29 & 0.233 \\
\hline & positive & 25 & 53.63 & 7.50 & \\
\hline \multirow[t]{2}{*}{ Serum MPO $(\mathrm{U} / \mathrm{ml})$} & negative & 24 & 0.64 & 0,28 & 0.487 \\
\hline & positive & 25 & 0.62 & 0,20 & \\
\hline \multirow[t]{2}{*}{ Whole Blood MPO $(\mathrm{U} / \mathrm{ml})$} & negative & 24 & 67.44 & 25.04 & 0.218 \\
\hline & positive & 25 & 71.13 & 20.93 & \\
\hline
\end{tabular}

Table 3 Synovial fluid oxidant activity; MDA and MPO levels, and antioxidant activity; CAT and GSH-Px levels in anti-CCP(+) and anti-CCP(-) patients with RA.

\begin{tabular}{|c|c|c|c|c|c|}
\hline & Anti-CCP antibody & $\mathbf{N}$ & Mean & Std. Deviation & p value \\
\hline \multirow[t]{2}{*}{ Synovial GSHpx (U/ml) } & negative & 24 & 0.072 & 0.027 & 0.432 \\
\hline & positive & 25 & 0.074 & 0.032 & \\
\hline \multirow[t]{2}{*}{ Synovial CAT $\left(k \mathrm{ml}^{-1}\right)$} & negative & 24 & 0.156 & 0.088 & 0.324 \\
\hline & positive & 25 & 0.145 & 0.086 & \\
\hline \multirow{2}{*}{$\begin{array}{l}\text { Synovial MDA } \\
(\mathrm{nmol} / \mathrm{ml})\end{array}$} & negative & 24 & 2.852 & 0.509 & $0.021^{*}$ \\
\hline & positive & 25 & 4.592 & 0.780 & \\
\hline \multirow[t]{2}{*}{ Synovial MPO (U/ml) } & negative & 24 & 3.134 & 2.125 & $0.037^{*}$ \\
\hline & positive & 25 & 4.783 & 2.654 & \\
\hline
\end{tabular}


Table 4. Synovial fluid MDA and MPO levels of the subjects whom ESR was below $28 \mathrm{~mm} / \mathrm{h}$ in anti-CCP(+) and anti-CCP(-) groups.

\begin{tabular}{llllll}
\hline & Anti-CCP antibody & $\mathbf{N}$ & Mean & Std. Deviation & p value \\
\hline $\begin{array}{l}\text { Synovial MDA } \\
\text { (nmol/ml) }\end{array}$ & negative & 12 & 2.912 & 0.712 & $0.048^{*}$ \\
Synovial MPO $(\mathrm{U} / \mathrm{ml})$ & positive & 10 & 4.314 & 0.780 & $0.032^{*}$ \\
& negative & 12 & 3.303 & 1.865 & 2.476 \\
\hline
\end{tabular}

${ }^{*} \mathrm{p}<0.05$
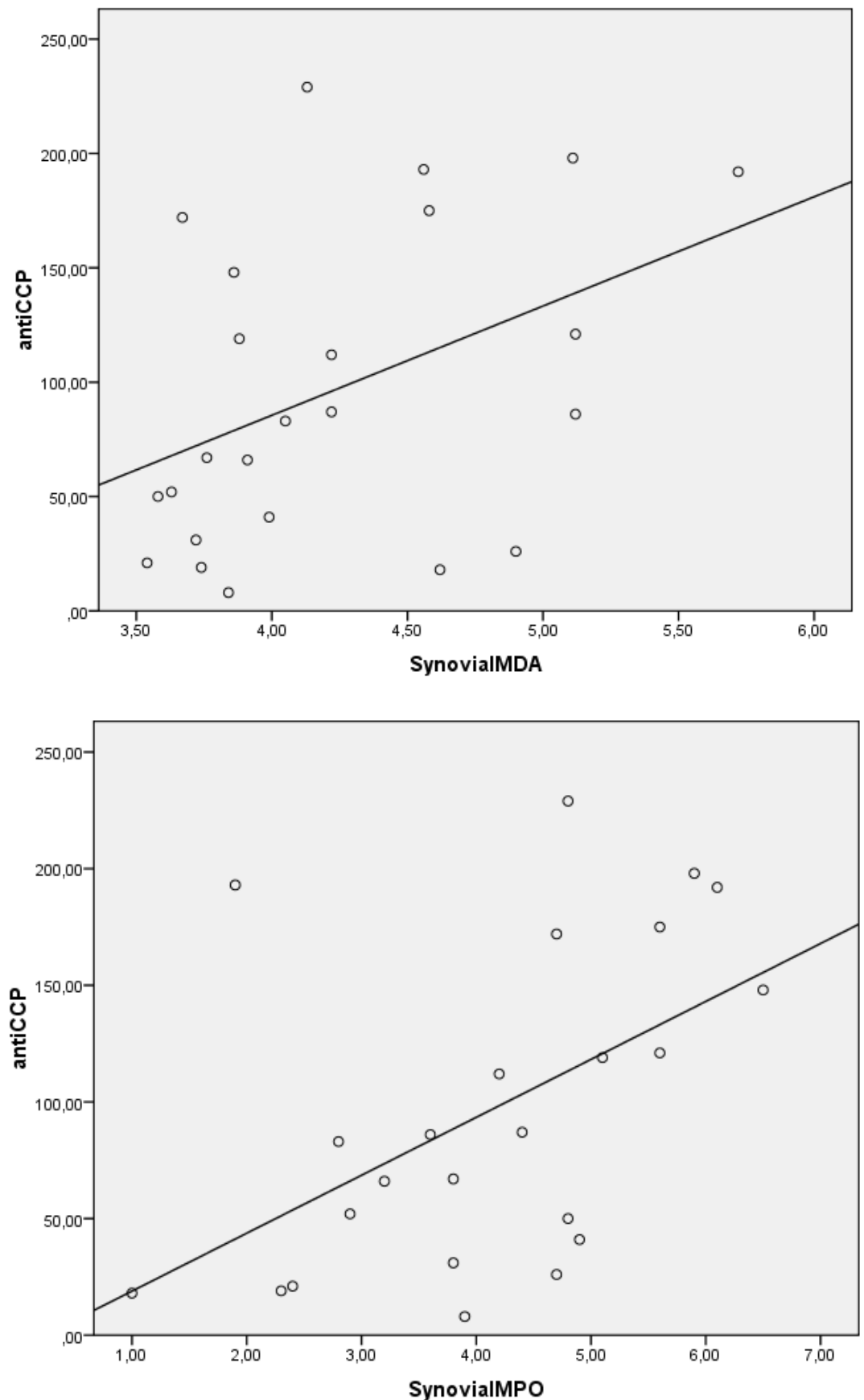

Fig I. There were significant correlations between the antibodies against citrullinated peptide (CCP-AB) levels and synovial MDA and MPO levels $(r=0.435, p<0.05, r=0.563, p<0.05$ respectively) in the anti-CCP $(+) R A$ population. 

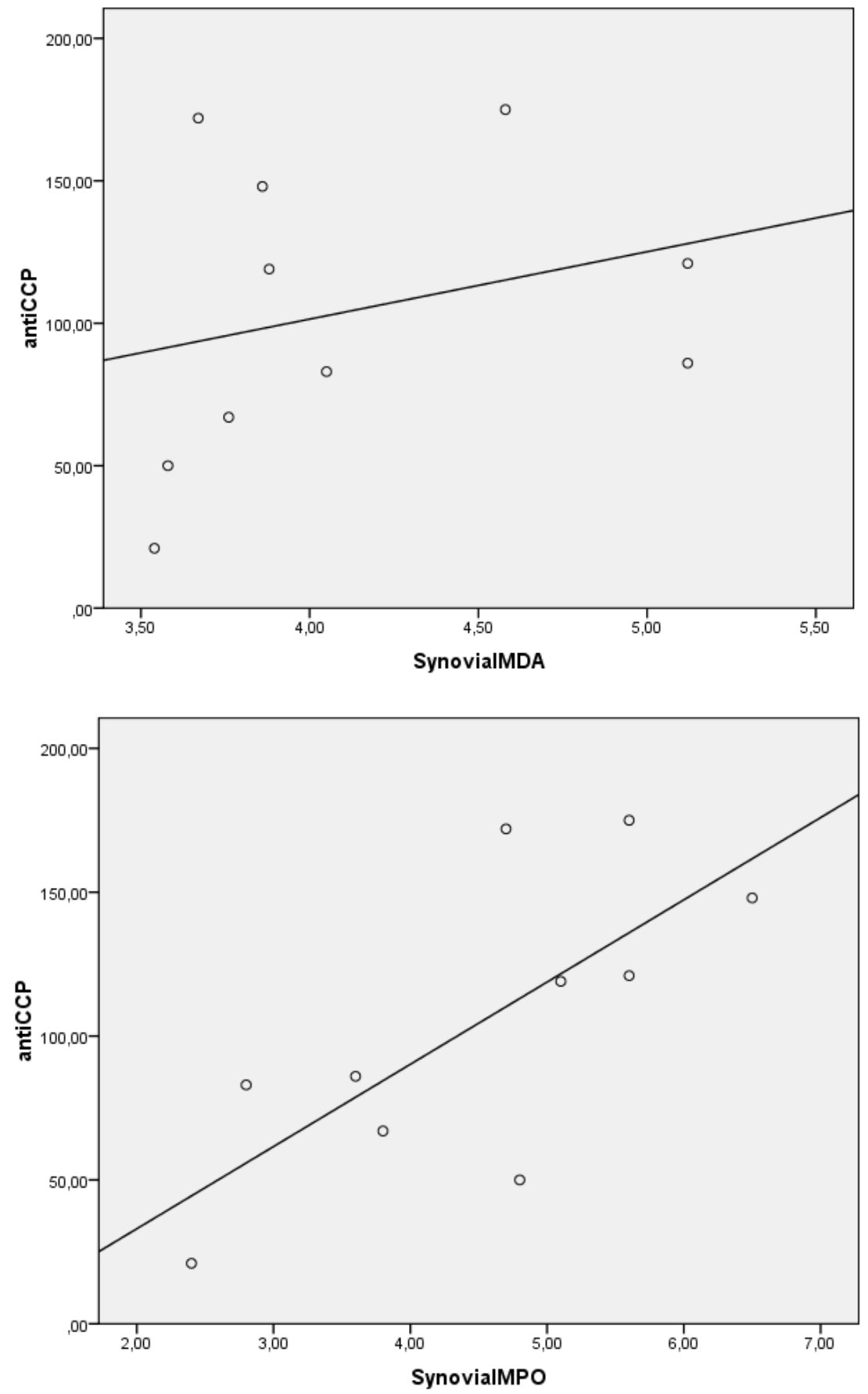

Fig 2. There was significant correlation between the antibodies against citrullinated peptide (CCP-AB) levels and synovial fluid MPO levels $[(r=0.693, p<0.05$, but not synovial fluid MDA levels, $r=0.480, p>0.05)]$ of the subjects whom ESR was below $28 \mathrm{~mm} / \mathrm{h}$ in anti-CCP(+) group.

\section{Discussion}

In the current study, we evaluated the relationship between serum anti-CCP antibody positivity and whole blood, serum and synovial fluid oxidant as well as antioxidant capacity in patients with RA, and we found positive correlations between anti-CCP antibody existence in circulation and increased oxi- 
dant activity (increased MDA and MPO levels) in the synovial fluids of patients with RA. But no relationship between anti-CCP antibody existence and blood and serum oxidant activity and antioxidant defense system were found. Also we found no significant differences in terms of the mean synovial antioxidative activity (CAT, GSHpx) values between anti-CCP $(+)$ and anti-CCP(-) RA patients.

RA patients positive for anti-CCP represent a subset of RA that is characterized by an aggressive disease course, including bone erosion $[10,20]$. Indeed, Anti-CCP is strongly associated with both prevalent tissue erosions and the development of erosions in RA joint tissues [1]. A high disease specificity of anti-CCP coupled with reasonable sensitivity and high predictive value for RA progression and radiological damage suggest that anti-CCP may play an important role in RA pathogenesis. Anti-CCP antibodies may also be related increased oxidative activity in RA patients. Anti-CCP antibodies are directed against antigens containing the nonstandard amino acid citrulline, for example, citrullinated fibrin, which is found in the rheumatoid joint [21]. The citrulline moiety, which is the essential part of the antigenic determinant in these antigens, is post-translationally generated by peptidyl arginine deiminases (PAD) [22]. Some reults in the literature also suggest that anti-CCP may be related increased oxidative activity in RA patients. For example, TNF-alpha inhibitors act as a regulator against pentosidine formation, oxidative DNA damage, and lipid peroxidation and is associated with a decrease in serum levels of oxidative stress markers, and also anti-CCP antibody levels in RA patients $[23,24]$.

Although the pathophysiological basis of RA is not yet fully understood, free radicals/ROS have been implicated in its pathogenesis [25], and several studies have demonstrated increased oxidative enzyme activity along with decreased, increased or unchanged antioxidant levels in RA sera and synovial fluids [26-28]. Our study may also explain these different results in RA patients, because previous studies did not allocate the subjects according to the anti-CCP antibody positivity. Antioxidants and oxidative enzymes have been shown to ameliorate arthritis in animal models [29]. Studies of RA synovial fluid and tissue have also demonstrated oxidative damage to hyaluronic acid, low-density-lipid proteins (LDL), proteins, cartilage, extracellular collagen, and intracellular DNA $[30,31]$. These are highly reactive transient chemical species (nitric oxide (NO), superoxide anion, hydrogen peroxide (H2O2), and hydroxyl radical (OHS), with the potential to initiate cellular damage in joint tissues especially in RA. They are formed by phagocyte activation during inflammation.
The current study showed no relationship between anti-CCP antibody existence and blood and serum antioxidant defense system (CAT, GSHpx). There were no statistically differences in both groups (anti-CCP(+) and anti-CCP(-)) in terms of blood and serum oxidant activity and antioxidant defense system. Cells and tissues are protected from ROS-induced damage by a variety of endogenous ROS scavenging proteins, enzymes, and chemical compounds. If these ROS are not scavenged by antioxidant mechanisms, these species may lead to widespread lipid, protein, and DNA damage in cells and tissues of patients with RA [5]. Several antioxidant systems such as superoxide dismutase (SOD), CAT, and GSH-Px dependent mechanisms which have different activities have been reported. SOD, the first line of defense against ROS, catalyzes the dismutation of the superoxide anion into hydrogen peroxide. Hydrogen peroxide can then be transformed into $\mathrm{H} 2 \mathrm{O}$ and $\mathrm{O} 2$ by CAT. GSH-Px is a selenoprotein which reduces lipidic or nonlipidic hydroperoxides as well as $\mathrm{H} 2 \mathrm{O} 2$ while oxidizing glutathione [32].

In this study, we found a positive correlation between anti-CCP antibody levels and increased oxidant (MDA and MPO) activity in the synovial fluid of patients with RA. One of the end-products of lipid peroxidation (LPO) damage is MDA which was found to be increased because of the reduced antioxidant defense system in patients with RA. Elevated levels of this end-product have been reported in the serum, plasma and synovial fluid in patients with RA [29]. But no change in plasma MDA levels has also been reported [33]. The decreased plasma total antioxidant capacity (TAC) levels and increased MDA and erithrocyte sedimentation rate (ESR) in patients with RA were reported in the previous studies and may be related to the severity of RA [26-28,34]. MPO is a heme-containing peroxidase. Enzymatically active MPO, together with hydrogen peroxide and chloride, produces the powerful oxidant hypochlorous acid and is a key contributor to the oxygen-dependent tissue damage in chronic inflammatory diseases [35]. Our study showed a relationship between increased synovial fluid MPO and anti-CCP antibody positivity.

A previous study revealed that the levels of anti-CCP antibodies are higher in synovial fluid than in serum [36]. It was also demonstrated that antibodies to the citrullinated antigens were produced and enriched in the joints of the RA patients [11]. This may explain why synovial fluid oxidative stress markers (MPO and MDA levels) were increased while serum oxidative stress markers were normal in this study. If anti-CCP antibody levels in synovial fluid were 
measured, it could have been provide more information in this study. But, because a limited number of our anti-CCP antibody kit, we thought to detect anti-CCP antibody levels in serum would be sufficient for the purpose of this study.

Limitations of the current study; i. Small sample size which leads to lower statistical power. ii. anti-CCP antibodies were not detected in synovial fluid and iii. DAS-28 scores, morning stiffness time and tender joint count at the assessment time were higher in anti-CCP $(+)$ group.

In conclusion; In the current study, we found relationships between anti-CCP antibody existence and increased MPO and MDA levels (oxidant activity) in the synovial fluid of patients with RA. But there were no relationships between anti-CCP antibody existence and whole blood and serum oxidant status and antioxidant defense system. Anti-CCP antibody positivity seems to be associated with increased synovial fluid oxidant activity (increased MDA and MPO levels) in patients with RA. And this increased oxidative activity in synovial fluid may be one of the responsible factors for accelerated bone erosions seen in anti-CCP positive RA patients. These conclusions need to be validated in a larger controlled study population.

\section{Conflict of Interest}

The authors have declared that no conflict of interest exists.

\section{References}

1. Bukhari M, Thomson W, Naseem H, Bunn D, Silman A, Symmons D, Barton A. The performance of anti-cyclic citrullinated peptide antibodies in predicting the severity of radiologic damage in inflammatory polyarthritis: results from the Norfolk Arthritis Register. Arthritis Rheum 2007;56:2929-2935.

2. Cuzzocrea S. Role of nitric oxide and reactive oxygen species in arthritis. Curr Pharm Des 2006;12:3551-3370.

3. Hagfors L, Leanderson P, Skoldstam L, Andersson J, Johansson G. Antioxidant intake, plasma antioxidants and oxidative stress in a randomized, controlled, parallel, Mediterranean dietary intervention study on patients with rheumatoid arthritis. Nutr J 2003;2:5.

4. Ostrakhovitch EA, Afanas'ev IB. Oxidative stress in rheumatoid arthritis leukocytes: suppression by rutin and other antioxidants and chelators. Biochem Pharmacol 2001; 62:743-746.

5. Gambhir JK, Lali P, Jain AK. Correlation between blood antioxidant levels and lipid peroxidation in rheumatoid arthritis. Clin Biochem 1997;30:351-155.

6. Kiziltunc AC, Ogalgil S, Cerrahoglu L. Carnithine and antioxidants levels in patients with rheumatoid arthritis. Scand J Rheumatol 1998;27:441-445.

7. Cerhan JR, Saag KG, Merlino LA, Mikuls TR, Criswell LA. Antioxidant micronutrients and risk of rheumatoid arthritis in a cohort of older women. Am J Epidemiol 2003;157:345-354.

8. Paredes S, Girona J, Hurt-Camejo E, Vallve JC, Olive S, Heras $\mathrm{M}$, Benito P, Masana L. Antioxidant vitamins and lipid peroxi- dation in patients with rheumatoid arthritis: association with inflammatory markers. J Rheumatol 2002; 29:2271-2277.

9. Mulherin DM, Thurnham DI, Situnayake RD. Glutathione reductase activity, riboflavin status, and disease activity in rheumatoid arthritis. Ann Rheum Dis 1996;55:837-840.

10. Ronnelid J, Wick MC, Lampa J, Lindblad S, Nordmark B et al. Longitudinal analysis of citrullinated protein/peptide antibodies (anti-CP) during 5 year follow up in early rheumatoid arthritis: anti-CP status predicts worse disease activity and greater radiological progression. Ann Rheum Dis 2005;64:1744-1749.

11. Snir O, Widhe M, Hermansson M, von Spee C, Lindberg J et al. Antibodies to several citrullinated antigens are enriched in the joints of rheumatoid arthritis patients. Arthritis Rheum 2010;62:44-52.

12. Silveira IG, Burlingame RW, von Mühlen CA, Bender AL, Staub HL. Anti-CCP antibodies have more diagnostic impact than rheumatoid factor (RF) in a population tested for RF. Clin Rheumatol 2007;26:1883-1889.

13. Kuhn KA, Kulik L, Tomooka B, Braschler KJ, Arend WP et al. Antibodies against citrullinated proteins enhance tissue injury in experimental autoimmune arthritis. J Clin Invest 2006;116:961-973.

14. Arnett FC, Edworthy SM, Bloch DA, McShane DJ, Fries JF et al. The American Rheumatism Association 1987 revised criteria for the classification of rheumatoid arthritis. Arthritis Rheum 1988;31:315-324.

15. Placer ZA, Cushman L, Johnson BC. Estimation of products of lipid peroxidation (malonyl dialdehyde) in biological fluids. Anal Biochem 1966;16:359-364.

16. Aebi H. Catalase. In: Bergmeyer HU, ed. Methods of enzymatic analysis, 3rd edn. New York: Academic Press. 1974: 673- 677.

17. Matkovics B, Szabo L,Varga IS. Determination of enzyme activities in lipid peroxidation and glutathione pathways. Laboratoriumi Diagnosztika 1988;15:248-249.

18. Bradley PP, Priebat DA, Christensen RD, Rothstein G. Measurement of cutaneous inflammation: estimation of neutrophil content with an enzyme marker. Journal of Investigative Dermatology 1982;78:206-209.

19. Wolfe F. The Many Myths of Erythrocyte Sedimentation Rate and C-Reactive Protein. J Rheumatol 2009;36:1568-1569.

20. Rantapaa-Dahlqvist S, de Jong BA, Berglin E, Hallmans G, Wadell $G$ et al. Antibodies against cyclic citrullinated peptide and IgA rheumatoid factor predict the development of rheumatoid arthritis. Arthritis Rheum 2003:48:2741-2749.

21. Vossenaar ER, Nijenhuis S, Helsen MM, van der Heijden A, Senshu $\mathrm{T}$ et al. Citrullination of synovial proteins in murine models of rheumatoid arthritis. Arthritis Rheum 2003;48:2489-2500.

22. Vossenaar ER, Zendman AJ, van Venrooij WJ, Pruijn GJ. PAD, a growing family of citrullinating enzymes: genes, features and involvement in disease. Bioessays 2003;25:1106-1118.

23. Kageyama Y, Takahashi M, Nagafusa T, Torikai E, Nagano A. Etanercept reduces the oxidative stress marker levels in patients with rheumatoid arthritis. Rheumatol Int 2008;28:245-251.

24. Atzeni F, Sarzi-Puttini P, Dell' Acqua D, de Portu S, Cecchini G et al. Adalimumab clinical efficacy is associated with rheumatoid factor and anti-cyclic citrullinated peptide antibody titer reduction: a one-year prospective study. Arthritis Res Ther 2006:8:R3.

25. Biemond P, Swaak AJ, Koster JF. Protective factors against oxygen free radicals and hydrogen peroxide in rheumatoid arthritis synovial fluid. Arthritis Rheum 1984;27:760-765.

26. De Leo ME, Tranghese A, Passantino M, Mordente A, Lizzio $\mathrm{MM}$ et al. Manganese superoxide dismutase, glutathione peroxidase, and total radical trapping antioxidant capacity in active rheumatoid arthritis. J Rheumatol 2002;29:2245-2246. 
27. Taysi S, Polat F, Gul M, Sari RA, Bakan E. Lipid peroxidation, some extracellular antioxidants, and antioxidant enzymes in serum of patients with rheumatoid arthritis. Rheumatol Int 2002;21:200-204.

28. Cimen MY, Cimen OB, Kacmaz M, Ozturk HS, Yorgancioglu R, Durak I. Oxidant/antioxidant status of the erythrocytes from patients with rheumatoid arthritis. Clin Rheumatol 2000;19:275-277.

29. Bandt MD, Grossin M, Driss F, Pincemail J, Babin-Chevaye C, Pasquier C. Vitamin E uncouples joint destruction and clinical inflammation in a transgenic mouse model of rheumatoid arthritis. Arthritis Rheum 2002;46:522-532.

30. Hitchon CA, El-Gabalawy HS. Oxidation in rheumatoid arthritis. Arthritis Res Ther 2004;6:265-278.

31. Dai L, Lamb DJ, Leake DS, Kus ML, Jones HW et al. Evidence for oxidised low density lipoprotein in synovial fluid from rheumatoid arthritis patients. Free Radic Res 2000;32:479-486.

32. Michiels C, Raes M, Toussaint O, Remacle J. Importance of Se-glutathione peroxidase, catalase, and $\mathrm{Cu} / \mathrm{Zn}-\mathrm{SOD}$ for cell survival against oxidative stress. Free Radic Biol Med 1994;17:235-248.

33. Kamanli A, Naziroglu M, Aydilek N, Hacievliyagil C. Plasma lipid peroxidation and antioxidant levels in patients with rheumatoid arthritis. Cell Biochem Funct 2004;22:53-57.

34. Olivieri O, Girelli D, Trevisan MT, Bassi A, Zorzan P et al. Red blood cell susceptibility to lipid peroxidation, membrane lipid composition and antioxidant enzymes in patients with rheumatoid arthritis. J Rheumatol 1991;18:1263- 1264.

35. van der Veen BS, de Winther MP, Heeringa P. Myeloperoxidase: molecular mechanisms of action and their relevance to human health and disease. Antioxid Redox Signal 2009;11:2899-2937.

36. Vossenaar ER, Smeets TJ, Kraan MC, Raats JM, van Venrooij WJ, Tak PP. The presence of citrullinated proteins is not specific for rheumatoid synovial tissue. Arthritis Rheum 2004;50:3485-3494. 